\title{
PROWOKACJA W WALCE $Z$ „BANDAMI”. WYBRANE PRZYKŁADY NIEMIECKICH AKCJI PROWOKACYJNYCH Z TERENU DYSTRYKTU KRAKOWSKIEGO GG
}

\section{Dawid Golik}

Instytut Pamięci Narodowej, Oddział w Krakowie

\author{
ABSTRACT \\ PROVOCATION IN THE FIGHT AGAINST "BANDS." SELECTED \\ EXAMPLES OF GERMAN PROVOCATIVE ACTIONS IN THE KRAKÓW \\ DISTRICT OF THE GENERAL GOVERNMENT
}

In 1943 the Germans started using agent-provocateur units composed of members of different police formations to combat the independent and communist underground movements in the territories of occupied Poland. Their members, pretending to be Polish or Soviet partisans, contacted local people and subsequently arrested or liquidated the most dangerous activists of the underground. There were several agent-provocateur units operating in the Kraków district of the General Government, and their most intense activity was reported in the Podhale region and in the vicinity of Miechów.

Key words: agent-provocateur units, partisans, German police, occupation of Poland 1939-1945, General Government, German crimes, Polish Home Army, communists.

Słowa kluczowe: oddziały prowokacyjne, partyzanci, policja niemiecka, okupacja Polski 19391945, Generalne Gubernatorstwo, zbrodnie niemieckie, Armia Krajowa, komuniści.

Niemcy od samego początku wojny wykorzystywali do zwalczania polskiego podziemia konfidentów oraz wprowadzanych w jego szeregi agentów. Mimo że społeczeństwo polskie dalekie było od postaw kolaboracyjnych, to jednak klęska we wrześniu 1939 roku, a następnie kapitulacja sojuszniczej Francji w roku 1940 skutecznie podkopywały wiarę w szybkie zwycięstwo nad Niemcami. Skłaniały też niektórych obywateli II Rzeczypospolitej do podjęcia decyzji o współpracy z okupantem, a niekiedy do czynnego wspierania go w zwalczaniu tworzącego się podziemia oraz informowania o jego poczynaniach. Informatorzy, działając według wytycznych 
niemieckiej policji bezpieczeństwa i służby bezpieczeństwa, rozpracowywali struktury organizacyjne podziemia i albo doprowadzali do ich natychmiastowego rozbicia, albo też do przejęcia kontroli nad ich funkcjonowaniem. $Z$ kolei z chwilą, kiedy na terenie Polski zaczęły pojawiać się pierwsze grupy zbrojne, starano się wszelkimi sposobami zdobywać informacje na ich temat, a następnie likwidować je w trakcie operacji przeciwpartyzanckich. Niekiedy w tych działaniach wykorzystywano jako wywiadowców funkcjonariuszy złożonej z Polaków tzw. granatowej policji oraz mówiących po polsku żandarmów i pracowników Sipo (zarówno z pionu Gestapo, jak i z policji kryminalnej - Kripo, w której na etatach zatrudniano także Polaków) ${ }^{1}$. W celu uzyskiwania dokładnych informacji o oddziałach partyzanckich często wysyłano też w teren ubranych po cywilnemu funkcjonariuszy, którzy przedstawiali się jako zbiegowie albo organizatorzy oporu poszukujący kontaktów z podziemiem, lub też ludzi udających turystów. W takim właśnie charakterze w czerwcu 1943 roku wysłano w Gorce dwóch ,granatowych” policjantów - Józefa Benala i Bernarda Kirsteina. Dotarli oni między 15 a 20 czerwca 1943 roku do schroniska na Turbaczu. Tam kierująca obiektem Michalina Szczygieł rozpoznała Benala i ostrzegła o niebezpieczeństwie kwaterujących w pobliżu konspiratorów z grupy Józefa Kurasia „Orła”, wywieszając przed schroniskiem białe prześcieradło. Następnego dnia ludzie „Orła” przygotowali zasadzkę i obydwu policjantów zlikwidowano².

Nie zawsze jednak podziemiu udawało się w porę zareagować na tego typu działania. Kilka miesięcy później, także na Podhalu, do jednego z gospodarstw w Knurowie przyszli przebrani za partyzantów dwaj niemieccy policjanci - najprawdopodobniej thumacz Gestapo w Zakopanem Bruno Mazurkiewicz i funkcjonariusz Sipo ze Szczawnicy, pochodzący ze Śląska i mówiący po polsku, SS-Oberscharführer Josef König. Wspominał to Jan Warmuz:

Gdzieś już po północy [7 października 1943 r.] do młyna przyszli dwaj mężczyźni, ubrani w polskie wojskowe mundury. Pytali o Ludwika Warmuza, który akuratnie schodził ze strychu. [...] Przybyli oświadczyli, że chcą z nim rozmawiać. Poszli do niego na strych i tam przedstawiali się jako partyzanci i nakłaniali do pójścia z nimi. Pytali też, czy nie zna kogoś, kto przyłączyłby się do nich. Usłyszeli stuk żelaza na strychu, gdzie ukrył się Stanisław Borowicz. Odszukali go, oświadczając, że są z Armii Podziemnej Wojska Polskiego. [...] Ludwik Warmuz zawołał śpiącego już swojego szwagra - Jana Trutego. Truty zabrał z domu chleb i mleko i wyszedł z Ludwikiem Warmuzem. Skoro znaleźli się za młynem przed tartakiem, wtedy przybyli

1 Poza Policją Polską Generalnego Gubernatorstwa, którą nazywano potocznie „granatową”, funkcjonowała także Polska Policja Kryminalna. W odróżnieniu od policji „granatowej” członkowie tej formacji pełnili swoją służbę w cywilu i formalnie wchodzili w skład struktur niemieckiej policji bezpieczeństwa i służby bezpieczeństwa (Sicherheitspolizei und Sicherheitsdienst, Sipo und SD). Zob. m.in. A. Hempel, Pogrobowcy klęski. Rzecz o policji „,granatowej” w Generalnym Gubernatorstwie 1939-1945, Warszawa 1990.

2 M. Korkuć, Józef Kuraś „Ogień”. Podhalańska wojna 1939-1945, Kraków 2011, s. 118-121; J. Sral, Pamiętnik Krasnego, rkps, [b.m.d.], s. 9-11; M. Maciaszek, Od „Orta” do „Zawiszy”. Gorce 1943, Nowy Targ 2010, s. 18-26. W odwecie za likwidację tej dwójki w nocy 29 czerwca 1943 r. grupa przebranych w ubrania cywilne ludzi, wśród których rozpoznano m.in. szefa nowotarskiej Kripo SS-Untersturmführera Josefa Kandzię, zamordowała ojca „Orła”, jego żonę i dwuipółletniego syna. 
dwaj mężczyźni oświadczyli im, że oni są gestapowcami z Gestapo w Zakopanem i aresztują ich $^{3}$.

Od razu wyciągnęli kajdanki i skuli nimi Trutego i Borowicza, natomiast Ludwik Warmuz, korzystając z nieuwagi ,przebierańców”, zdołał zbiec. Po krótkim przesłuchaniu obydwaj zatrzymani tej nocy Polacy zostali zastrzeleni ${ }^{4}$.

Także w kolejnych miesiącach w górach pojawiali się podejrzani wędrowcy spisujący w notatnikach wszelkie spostrzeżenia na temat funkcjonowania miejscowej AK. W maju 1944 roku w okolice Słopnic pod Limanową wysłano dwóch polskich pracowników Komisariatu Policji Kryminalnej w Nowym Sączu - Józefa Płachtę i Jana Krawczyńskiego. Zostali jednak w porę rozpoznani przez żołnierzy miejscowej placówki AK i rozbrojeni. Jak wspominał Tadeusz Czech „Wicek”:

Doprowadziliśmy ich w pobliże domostwa zajętego przez dowództwo zgrupowania. Z dokumentów odebranych ujętym wynikało, że obaj są pracownikami „Kripo” [...] w Nowym Sączu. Kilka osób przybyło aby przebadać „kripowców”. Okazało się, że Krawczyński przedwojenny policjant granatowy obecnie wysługujący się Niemcom, był „,grubszą zwierzyną” dawno przez nasz Sąd Specjalny przeznaczony na „odstrzał” za winy względem Polaków5

Krawczyńskiego zlikwidowano na miejscu, natomiast dochodzenie w sprawie Płachty i jego rzekomych kontaktów z wywiadem AK (starał się ratować życie, oferując swoje usługi podziemiu) trwało jeszcze kilka tygodni. Okazało się jednak, że nie można mu ufać i rozstrzelano go na początku czerwca 1944 roku$^{6}$.

Tego typu działania, choć ryzykowne, nie zawsze jednak były dla Niemców wystarczająco skuteczne, i mimo że kontynuowano je aż do końca okupacji, to w pewnym momencie zaczęto wcielać w życie także bardziej skomplikowane metody likwidacji podziemnych grup zbrojnych. Niewykluczone, że pomysł wykorzystywania w działaniach przeciw podziemiu oddziałów prowokacyjnych narodził się po pozytywnych efektach, jakie zanotowali Niemcy, wykorzystując do zwalczania partyzantki w Generalnym Gubernatorstwie lotne oddziały policyjne, funkcjonujące jako oddziały pościgowe (Jagdkommando) lub tzw. grupy patrolowe (Streifenkommando). Organizowały je w czasie wojny poszczególne plutony żandarmerii, także te w dystrykcie krakowskim, i wykorzystywały doraźnie do zwalczania pospolitych grup bandyckich, będących plagą GG, oraz oddziałów zbrojnego podziemia. Oddziały pościgowe były grupami policyjnymi mającymi oczekiwać w gotowości bojowej na

3 Archiwum Oddziałowej Komisji Badania Zbrodni przeciwko Narodowi Polskiemu IPN w Krakowie, S 9/76, Rozstrzelanie 22 Polaków na terenie gminy Chochołów (w Chochołowie, Dzianiszu i Witowie) w okresie od stycznia 1940 do 1944 r. [dalej: AOKBZpNP IPN w Krakowie, S 9/76], Protokół przesłuchania świadka Jana Warmuza, 23 sierpnia 1978 r., k. 178.

4 Ibidem, Protokół przesłuchania świadka Albiny Borowicz, 24 sierpnia 1978 r., k. 182; ibidem, Postanowienie o częściowym zawieszeniu i częściowym umorzeniu śledztwa, 20 listopada 1978 r., [b.p.]; Relacja Marii Solana (z d. Warmuz) z 24 stycznia 2009 r. (ze zbiorów autora). Innym podejrzanym o udział w akcji na terenie Knurowa był tłumacz zakopiańskiej placówki Sipo Roman Knieciński.

5 T.L. Czech „Wicek”, Tym groźniejszy, że zdecydowany zginać, Stary Sącz 1989 [wydanie na prawach rękopisu], s. 121. Zachowano oryginalną interpunkcję. Dopiski w nawiasach kwadratowych pochodzą od autora artykułu.

6 Ibidem, s. 124. 
przejawy wrogiej działalności ze strony Polaków, a po otrzymaniu informacji o danym zdarzeniu natychmiast ruszać w pościg za sprawcami i, o ile było to możliwe, likwidować „bandy”. Takie oddziały funkcjonowały m.in. w 1943 roku w powiecie miechowskim i składały się z niemieckich żandarmów oraz polskich funkcjonariuszy „granatowej” policji. Z czasem ich rola malała na rzecz przerzucanych do konkretnych powiatów zmotoryzowanych plutonów żandarmerii lub też kompanii i batalionów policji ochronnej.

Z kolei grupy patrolowe stanowiły specyficzny rodzaj oddziałów pościgowych, które miały nie tylko tropić i likwidować oddziały partyzanckie, ale też kontrolować teren i zbierać informacje. Dobrym przykładem wykorzystania ich w dystrykcie krakowskim może być aktywność plutonu żandarmerii Sanok (Gendarmerie-Zug Sanok), który w marcu 1944 roku stworzył na terenie powiatu sanockiego tego typu grupę. Składała się ona $\mathrm{z}$ oficera niemieckiej żandarmerii, 4 żandarmów, 2 funkcjonariuszy Sonderdienstu (w tym thumacza) oraz 15 polskich „granatowych” policjantów. Oddział, którym dowodził Bezirk-Leutnant der Gendarmerie Walter Schmidt z posterunku żandarmerii w Ustrzykach Dolnych, był bardzo dobrze uzbrojony i wyposażony. Każdy żandarm posiadał pistolet maszynowy, a pozostali członkowie grupy broń sowiecką - długie karabiny Mosin oraz sowiecki ręczny karabin maszynowy? Zadanie, jakie miała wykonywać grupa, nakreślono dość szeroko:

Oddział patrolowy żand[armerii] otrzymuje zadanie nawiązania kontaktu na terenie gmin zbiorczych Ustrzyki Dolne, Czarna, Lutowiska i Stuposiany ze znajdującymi się tam placówkami policji porządkowej i policji bezpieczeństwa oraz Wehrmachtu, wyszukania burmistrzów i wójtów w celu przesłuchania i wymiany informacji, skontrolowania służby wart chroniących miejscowości, rozpoznania w odpowiednim momencie tworzenia się nowych band, ścigania i niszczenia na miejscu mniejszych band ${ }^{8}$.

Grupa miała funkcjonować, z krótkimi przerwami na uzupełnienie wyposażenia oraz odpoczynek na miejscowych posterunkach, przez okres trzech tygodni. W tym czasie swobodnie przemieszczała się $\mathrm{w}$ terenie (tak jak oddział partyzancki), zbierała informacje i w razie potrzeby dokonywała obław na członków podziemia. I mimo że policjanci działali w mundurach i nie podszywali się pod jakąkolwiek grupę zbrojną, to jednak metody, jakimi się posługiwali, przypominały te, które charakteryzowały właśnie oddziały prowokacyjne.

Najprawdopodobniej doświadczenia zebrane podczas wykorzystywania oddziałów pościgowych i patrolowych spowodowały, że w 1943 roku na terenie dystryktu krakowskiego GG zaczęły funkcjonować pierwsze niemieckie oddziały prowokacyjne, określane w dokumentach okupanta jako tzw. kontrbandy (Gegenbande). Jeden z pierwszych tego typu przypadków zanotowano w maju 1943 roku w okupacyjnym powiecie jasielskim, gdzie ubrany po cywilnemu oddział wywiadowczy złożony z czterech polskich „granatowych” policjantów, na którego czele stał

Archiwum Państwowe w Przemyślu, Zespół nr 24, Starostwo Powiatowe w Sanoku, sygn. 33, Polizeibeamte. Einsatz der deutschen Gendarmerie 1940-1944 [dalej: AP Przemyśl, Zespół nr 24, sygn. 33], Gend,-Zug Sanok Distrikt Krakau Tgb. Nr 417/44, An die Gendarmeriepostenführer in Sanok - Nisko - Ustrzyki Dolne, Sanok, 6 marca 1944 r., k. 23, 25.

8 Ibidem, k. 23. 
Rottwachtmeister der Gendarmerie Karl Perschke, zdołał udaremnić 18 maja 1943 roku atak oddziału zbrojnego na dwór w Błażkowej koło Jodłowej. W czasie walki, jaka wówczas rozgorzała, zginęło czterech partyzantów, a reszta się wycofała. Wprawdzie nie wiadomo, czy prowokatorzy połączyli się wcześniej z atakującą grupą i dopiero w ostatniej chwili otworzyli do jej członków ogień, czy też do walki doszło przypadkowo w czasie spotkania, ale pokładane w oddziale nadzieje musiały zostać spełnione, skoro dokonania żandarma Perschke z posterunku żandarmerii w Jaśle pochwalono w Rozkazie Dziennym Dowódcy Żandarmerii w Dystrykcie Krakowskim z 27 maja 1943 roku9. Efekty funkcjonowania „kontrbandy” w tym powiecie były na tyle zadowalające, że podobne działania podjęto w kolejnych miesiącach, wysyłając $\mathrm{w}$ pole $\mathrm{m}$.in. pięcioosobowy oddział prowokacyjny dowodzony przez SS-Unterscharführera Theodora Drzysgę z Komisariatu Policji Granicznej w Jaśle, który latem 1943 roku przez trzy tygodnie udawał oddział partyzancki ${ }^{10}$. Znany jest też podobny przypadek z powiatu tarnowskiego, gdzie w czerwcu 1943 roku Unterwachtmeister der Gendarmerie Arthur Schielberg dowodził kilkuosobowym, ubranym po cywilnemu, oddziałem rozpoznawczym żandarmerii w rejonie Iwkowej i Tymowej ${ }^{11}$.

\section{PODHALAŃSKI POLIGON}

Wiosną 1943 roku na Podhalu pojawił się pierwszy oddział partyzancki dowodzony przez starszego bosmana Wojciecha Bolesława Duszę „Szarotę”. Nie był on związany z miejscowymi strukturami AK, jednakże utrzymywał kontakty z ruchem narodowym i najprawdopodobniej krakowskim dowództwem Ruchu „Miecz i Pług”12. Jego aktywność, polegająca przede wszystkim na likwidacji działaczy kierowanego przez Wacława Krzeptowskiego Komitetu Góralskiego oraz aktywistów związanych z ruchem Goralenvolku, była dla Niemców dużym zaskoczeniem i przez długi czas okupanci nie byli w stanie skutecznie jej się przeciwstawić ${ }^{13}$. Wszystko wskazuje na to, że przełomem w rozpracowaniu grupy Duszy było dopiero wykorzystanie w wal-

9 AP Przemyśl, Zespół nr 24, sygn. 33, Der Kommandeur der Gendarmerie im Distrikt Krakau, Tagesbefehl Nr 11, Krakau, 27 maja 1943 r., k. 113.

10 IPN GK 107/33, Wnioski awansowe policji niemieckiej, Vorschlag zur Verleihung des Kriegsverdienstkreuzes 2. Klasse mit Schwerter, Theodor Drzysga, Krakau, 14 lipca 1944 r., k. 31.

11 IPN GK 107/41, Wnioski awansowe policji niemieckiej [dalej: IPN GK 107/41], Vorschlag zur Verleihung des Kriegsverdienstkreuzes 2. Klasse mit Schwerten, Arthur Schielberg, Krakau, 9 lipca 1943 r., k. 126.

12 Wskazują na to m.in. zeznania Ludwika Sojki z Krauszowa, który wymienia osoby związane z oddziałem Duszy jako siatkę konspiracyjną Ruchu „Miecz i Pług”, utworzoną w lipcu 1943 r. przez płk. Jana Kubina z Krakowa. Zob. IPN Kr 010/9468, Akta operacyjne w sprawie Henryka Schwenka, Protokół przesłuchania Ludwika Sojki, Nowy Targ, 9 maja 1951 r., k. 262.

13 Więcej na temat działalności tego oddziału i represji, jakie w związku z tym dotknęły mieszkańców Podhala, zob.: D. Golik, Oddziat partyzancki Wojciecha Bolestawa Duszy „, Szaroty”, „Z Dziejów Walk o Niepodległość" 2015, t. 3, s. 258-283; Z. Sikora, Krwawy ślad. Nieznani bohaterowie Podhala, 
ce z nim wprowadzonych do oddziału agentów Gestapo, a następnie użycie grup prowokacyjnych do likwidacji współpracowników „Szaroty”.

Późnym latem lub jesienią 1943 roku nastąpiło przypadkowe aresztowanie jednego z podwładnych Duszy - Tadeusza Kontowicza (vel Januszewskiego) „Ogrodnika". Pomimo szczupłości zachowanych źródeł można najprawdopodobniej przypuszczać, że człowiek ten zgodził się za cenę ratowania własnego życia dostarczać informacji o oddziale. Drugim agentem, który mógł już dużo wcześniej współpracować z Niemcami, był przyprowadzony w lipcu 1943 roku do oddziału rzekomy uciekinier z KL Auschwitz - Edward Makówka „Czarny”, „Czarny Edek”. Możliwe, że od początku był on współpracownikiem niemieckim, mającym dostarczać informacji o działających w Małopolsce grupach zbrojnych (i na tej zasadzie wypuszczono go z Auschwitz) lub też Niemcy zdołali go zwerbować dopiero jesienią 1943 roku $^{14}$. Trzecim podwładnym „Szaroty”, który poszedł na współpracę z Niemcami, był z kolei Mieczysław Bittner „Thor” - złapany podczas obławy latem 1943 roku i złamany w trakcie śledztwa w siedzibie Komisariatu Policji Granicznej w Zakopanem ${ }^{15}$.

Rozpracowywanie oddziału wzięły na siebie zakopiańskie Gestapo oraz pluton żandarmerii z Nowego Targu, któremu jesienią 1943 roku do pomocy wysłano 63. zmotoryzowany pluton żandarmerii (Gendarmerie-Zug mot. 63), dowodzony przez podporucznika żandarmerii (Leutnant der Gendarmerie) Herberta Kreske ${ }^{16}$. Okupanci, mając swoich ludzi w oddziale, świadomie nie dokonali od razu jego likwidacji, lecz stopniowo pozyskiwali informacje o kolejnych punktach kontaktowych i sieci współpracowników Duszy. Kiedy uzyskano już wystarczającą ilość danych, zdecydowano się, nie dekonspirując przy tym najważniejszych agentów, rozpocząć aresztowania, wykorzystując do tego złamanego w śledztwie „Thora”. 8 września 1943 roku Bittner, wraz z dwoma „ochotnikami” do partyzantki (w rzeczywistości przebranymi w ubrania cywilne, mówiącymi po polsku funkcjonariuszami żandarmerii niemieckiej), przyszedł do punktu kontaktowego grupy w domu Władysława Szepelaka „Kasprowego” w Bielance, gdzie miał nadzieję spotkać „Szarotę”. Z uwagi na to, że go nie zastali, zapowiedzieli, że przyjdą o tej samej porze następnego dnia. Rzeczywiście 9 września 1943 roku przybyli do zabudowań Szepelaków - tym razem towarzyszyli im „granatowi” policjanci i Niemcy, spośród których zidentyfikowano m.in. tłumacza Gestapo w Zakopanem SS-Unterscharführera Adolfa Krupanka oraz policjanta z posterunku w Chochołowie Józefa Rozpędzika ${ }^{17}$. Podczas najścia zginął zastrzelony „Kasprowy”, jego matka Anna i uciekający przed Niemcami Bolesław Lachowski „Kos”. Aresztowano Władysława Szepelaka „Młodego”, Wiktorię Szepelak, nieletniego Mariana Szepelaka, Józefa Smardza oraz kobietę z Krakowa

\footnotetext{
Zakopane 2014. W tej części opracowania wykorzystałem obszerne fragmenty z opublikowanego przeze mnie w 2015 r. materiału poświęconego oddziałowi Duszy.

14 Zob. W. Szepelak, Ja przetrwatem..., Nowy Targ 2003, s. 82-83.

15 J. Kuczaj, Ocalić od zapomnienia, z. 2, Calgary 1998, s. 95.

16 Zob. P. Stachiewicz, Akcja Koppe, Warszawa 1975; Bundesarchiv Berlin-Lichterfelde, VBS 286/6400023894, Herbert Kreske; R 9361-III/107131, Herbert Kreske; www.volksbund.de [dostęp: 24.08.2016].

17 W. Szepelak, op. cit., s. $91-98$.
} 
o nieznanych personaliach. Wydarzenie to rozpoczęło falę dalszych aresztowań, które trwały do końca września ${ }^{18}$. Część z nich dokonywali przebrani za partyzantów żandarmi. Między innymi 23 września grupa prowokatorów wtargnęła do domu Ziębów w Bielance, szukając ukrywającego się w tym czasie wspólnie z Duszą Józefa Zięby. Żona Zięby - Maria - została przez nich wyprowadzona przed dom i zastrzelona ${ }^{19}$.

Poza agentami kluczową rolę w rozpracowywaniu grupy „Szaroty” i w jej fizycznej likwidacji odgrywali w tym czasie dwaj żandarmi z wysokogórskiego posterunku żandarmerii w Zakopanem - Unterwachtmeister der Hilfspolizei Bruno Holler oraz Unterwachtmeister der Hilfspolizei Anton Arkulare. Obaj byli przed wojną obywatelami polskimi, pochodzili jednak najprawdopodobniej z rodzin o korzeniach niemieckich i podczas okupacji zostali wpisani na volkslistę. Następnie zgłosili się ochotniczo do niemieckiej policji porządkowej, gdzie jako element mniej pewny zostali skierowani w szeregi policji pomocniczej i po przeszkoleniu wysłani na posterunek żandarmerii w Zakopanem ${ }^{20}$. Okazali się wyjątkowo zdolnymi funkcjonariuszami byli młodzi, biegle posługiwali się językiem polskim, stąd też mieli możliwość pracy po cywilnemu i podszywania się pod członków konspiracji. W swoich działaniach bardzo często korzystali też z pomocy polskich „granatowych” policjantów z posterunku w Chochołowie oraz udających partyzantów pospolitych przestępców z tolerowanej przez władze niemieckie szajki kryminalnej Józefa Pacpalocha „Freibilliga” z Szaflar ${ }^{21}$. To właśnie dzięki ich działaniom udało się 7 października 1943 roku wytropić i zlikwidować Duszę na terenie Białego Dunajca, a uczestniczący w akcji Holler został w związku z tym przedstawiony w listopadzie 1943 roku do odznaczenia Wojennym Krzyżem Zasługi z Mieczami 2. klasy22.

Śmierć Duszy stanowiła jednak dopiero wstęp do likwidacji całego oddziału i zastąpienia prawdziwych partyzantów prowokatorami, w pełni dyspozycyjnymi wobec niemieckich okupantów. Trzy dni po zasadzce na „Szarotę”, 10 października 1943 roku, Holler wraz z Arkularem zorganizowali kolejną akcję przeciwko ludziom z oddziału. Tego dnia w mieszkaniu małżeństwa Kałamackich w Zakopanem przebywali Gustaw Wojciechowski oraz Willi Gondol z oddziału „Szaroty”, a o ich pobycie w tym miejscu dowiedział się policjant z posterunku w Chochołowie, Andrzej Lewandowski, który przekazał tę informację Arkularemu i Hollerowi ${ }^{23}$. Obaj żandarmi

18 Ibidem, s. 27; A. Marczyński, Wojciech Bolestaw Dusza, ps. „Szarota”, w walce z okupantem hitlerowskim na Podhalu w latach 1941-1943, „Studia Historyczne” 1983, R. XXVI, s. 290; Rejestr miejsc i faktów zbrodni popetnionych przez okupanta hitlerowskiego na ziemiach polskich w latach 1939-1945. Województwo nowosąeckie, Warszawa 1984, s. 15.

19 J. Kuczaj, op. cit., s. 95.

20 IPN GK 107/41, Vorschlagliste Nr 3 für die Verleihung des Eisernen Kreuzes II. Klasse, Bruno Holler, Anton Arkulare, Krakau, 18 stycznia 1944 r., k. 19-20; ibidem, Vorschlag zur Verleihung des Kriegsverdienstkreuz 2. Klasse mit Schwerten, Bruno Holler, Krakau, 9 listopada 1943 r., k. 88. Zob. IPN Ka 047/417, Akta w sprawie Antoniego Arkulary.

21 A. Marczyński, op. cit., s. 292-293.

22 IPN GK 107/41, Vorschlag zur Verleihung des Kriegsverdienstkreuz 2. Klasse mit Schwerten, Bruno Holler, Krakau, 9 listopada 1943 r., k. 88.

${ }_{23}$ IPN Kr 07/926, Akta kontrolno-śledcze w sprawie Antoniego Arkularego [dalej: IPN Kr 07/926], Protokół przesłuchania świadka Aleksandra Kędryny, 23 czerwca 1945 r., k. 13; ibidem, Protokół prze- 
przyszli do zabudowań Kałamackich i, wprowadzeni przez Lewandowskiego, przyłączyli się do domowników, z którymi wspólnie pili alkohol. Żandarmi byli uzbrojeni w pistolety i czekali tylko na odpowiedni czas, żeby zlikwidować znajdujących się u Kałamackich partyzantów. Kiedy uznali, że taki moment nadszedł, wyciągnęli broń i rozpoczęli strzelaninę. W jej trakcie zginął broniący się Gondol, natomiast Gustaw Wojciechowski został ranny i ujęty ${ }^{24}$. Sam Arkulare po wojnie zeznawał, że wezwany na miejsce thumacz Gestapo Erik Klimczok rozkazał zastrzelić Marię Wojciechowską oraz Annę Kałamacką jako współpracowniczki „bandy”25. Niemcy odnotowali przy tym, że dzięki uzyskanym podczas akcji informacjom ,udało się unieszkodliwić dalszych 32 bandytów, względnie pomocników bandytów”26.

W powojennej relacji Aleksandra Kędryny odnaleźć można też ślady większej prowokacji szykowanej przez funkcjonariuszy niemieckiej żandarmerii i Gestapo. Wspominał on:

[...] koło g[o]dz. 11-tej w nocy zajechał powóz, przed mój dom z dwoma cywilami. Jeden z nich wszedł do kuchni i oświadczył mojej żonie, że jest z Warszawy z komendantem partyzantów, że jest ich 38-miu i że za wszelką cenę muszą Wojciechowskiego wydostać z P[a]lace, a ja muszę im w tym pomóc. Zebrać broń i ludzi i przystąpić do akcji. [...] W tym czasie byłem ukryty za drzwiami w pokoju, czekając z doniczką w ręku w razie gdyby chciał wejść do pokoju ten cywil to bym go tą doniczką rozbroił, gdyż poznałem, że jest to gestapowiec Krupanek, a nie żaden partyzant ${ }^{27}$.

W zastępstwie Kędryny zabrany został przez niemieckich żandarmów udających partyzantów jego syn oraz siostra Gustawa Wojciechowskiego. Prowokacja nie udała się jednak i jak relacjonował Kędryna:

Według opowiadań mego syna gestapowiec przed lokalem Karpowicza wręczał mu do ręki rewolwer, oświadczając, jak nas niemcy [tak w oryg.] będą zaczepiać to będziemy strzelać. Syn jednak rewolweru nie chciał przyjąć a idąc dalej zostali zaczepieni przez dwóch żandarmów i wylegitymowani. W czasie legitymowania, syn mój powiedział do tych żandarmów [zdając sobie sprawę z tego, że nie ma do czynienia z prawdziwymi partyzantami], aby i go i ciotkę ratowali, gdyż ten pan daje mu rewolwer aby strzelał do niemców. Po tych słowach synowi mojemu kazali uciekać do domu, a siostrę Wojciechowskiego zabrali na gestapo ${ }^{28}$.

W połowie października, już po zniknięciu ,Szaroty” i kolejnych aresztowaniach, na spotkaniu z członkami oddziału z Ludźmierza zjawił się „Ogrodnik”. Zauważono jednak u niego pistolet należący do Duszy, z którym ten nigdy się nie rozstawał.

słuchania świadka Stanisława Kałamackiego, 22 czerwca 1945 r., k. 14; ibidem, Protokół przesłuchania świadka Antoniego Wojciechowskiego, 21 czerwca 1945 r., k. 15. Zob. IPN Kr 07/1716, Akta kontrolno-śledcze w sprawie Andrzeja Lewandowskiego.

24 IPN GK 107/41, Vorschlagliste Nr 3 für die Verleihung des Eisernen Kreuzes II. Klasse, Bruno Holler, Anton Arkulare, Krakau, 18 stycznia 1944 r., k. 19-20; ibidem, Vorschlag zur Verleihung des Kriegsverdienstkreuz 2. Klasse mit Schwerten, Bruno Holler, Krakau, 9 listopada 1943 r., k. 88.

${ }_{25}$ IPN Kr 07/926, Protokół przesłuchania podejrzanego Antoniego Arkulary, 6 września 1945 r., k. 1.

26 IPN GK 107/41, Vorschlagliste Nr 3 für die Verleihung des Eisernen Kreuzes II. Klasse, Bruno Holler, Anton Arkulare, Krakau, 18 stycznia 1944 r., k. 20.

27 AOKBZpNP IPN w Krakowie, Ds 6/70, Zbrodnie funkcjonariuszy Gestapo w Zakopanem, Protokół przesłuchania Aleksandra Kędryny, 16 lipca 1945 r., k. 6.

28 Ibidem, k. 7. 
Wzbudziło to podejrzenia i od tej pory obawiano się „Ogrodnika”, demaskując go jako konfidenta niemieckiego ${ }^{29}$. Wciąż aktywnie działali też Holler i Arkulare. 18 listopada 1943 roku obaj żandarmi, wzmocnieni siedmioma ubranymi po cywilnemu ,granatowymi” policjantami, stworzyli patrol, z którym przeszli rejon Chochołowa, Ratułowa i Międzyczerwiennego. W Międzyczerwiennem znaleźli skrytkę z kilkoma sztukami broni, częściami ekwipunku oraz kompletnym mundurem policyjnym. Z kolei tydzień później, 28 listopada 1943 roku (lub 1 grudnia 1943 r.), dwaj ubrani po cywilnemu żandarmi zastrzelili w Podczerwonem Tomasza Harbuta i udzielającą mu schronienia Wiktorię Żegleń ${ }^{30}$.

Mniej więcej w tym samym czasie agent Makówka zaczął pojawiać się w miejscowościach, gdzie wcześniej działała grupa i tam przedstawiał się jako wysłannik „Szaroty”, a jeżeli był pewien, że rozmawia z osobami, które nigdy „Szaroty” nie poznały, to mówił, że to on jest Wojciechem Duszą. „Nosił przy sobie aktówkę «Szaroty», [...] chodził w jego kurtce, czasami wkładał góralskie spodnie. Był inteligentny, lecz mówił po polsku niepoprawnie, ze śląskim akcentem" ${ }^{\prime 31}$. Informacje od ludzi zapisywał po kryjomu w notatniku, w wyniku czego po jego wizycie z reguły przychodzili żandarmi i dokonywali aresztowań lub egzekucji. Kres działalności „Czarnego Edka” nastąpił 11 grudnia 1943 roku, kiedy napotkał on Michała Szeligę „Misia” oraz towarzyszącego mu Jana Gobera „Gołębia”. „Miś” zdołał odebrać mu pistolet i strzelił do niego, poważnie go raniąc. Makówkę pospiesznie przeszukano, znajdując przy nim notatki oraz dokumenty świadczące o tym, że jest on Polakiem ze Śląska. Miejscowy sołtys postanowił odwieźć rannego do szpitala w Nowym Targu, gdzie ten po kilku godzinach zmarł.

Wciąż działali jednak zarówno niemieccy żandarmi, jak i współpracujący z nimi „Ogrodnik” oraz grupa kryminalistów „Freibilliga”. 23 grudnia 1943 roku zamordowano związanych z podziemiem Bronisława Kuczka i Andrzeja Kurkowskiego z Dzianisza. Zdarzenie to zapamiętał Stanisław Kuczek:

W dniu 23 grudnia został wysłany w poszukiwaniu za nimi agent żandarmerii Budz Józef zwany Freiwillig [nie wiadomo, czy chodzi w tym wypadku rzeczywiście o Budza, czy też o Pacpalocha], który pod pretekstem, że się ukrywa przed niemcami, nawiązał kontakt z Kórkowskim [właśc. Kurkowskim] i Kuczkiem namawiając ich do ucieczki. Nieświadomi uciekając zostali postrzeleni przez Freiwilliga. Poczem ten ostatni udał się na żandarmerię do Chochołowa, meldując o zajściu. [...] matka Kórkowskiego zabrała swojego syna rannego chcąc go przewieźć do domu. W drodze spotkała się z żandarmami tj. z Arkularym, Cholerem [właśc. Hollerem], [policjantem polskim] Litwinem i Freiwilligem. Arkulary przystąpił pierwszy i zastrzelił ran-

29 A. Marczyński, op. cit., s. 293.

30 IPN GK 107/41, Vorschlagliste Nr 3 für die Verleihung des Eisernen Kreuzes II. Klasse, Bruno Holler, Anton Arkulare, Krakau, 18 stycznia 1944 r., k. 20. Rejestr miejsc i faktów zbrodni popetnionych przez okupanta hitlerowskiego na ziemiach polskich w latach 1939-1945. Województwo nowosadeckie, s. 21, 26-27, 89. Por. IPN GK 107/39, Wnioski awansowe policji niemieckiej, Vorschlagliste Nr 32 für die Verleihung des Kriegsverdientskreuzes 2. Klasse mit Schwerten, Paul Huhn, Krakau, 8 maja 1944 r., k. 27-28.

31 W. Budarkiewicz, Wspomnienia partyzanta podhalańskiego, mps, Nowy Targ 1986, s. 12. 
nego Kórkowskiego, następnie poszli dalej, gdzie leżał Kuczek ranny, tam też Arkulary dobił go strzałem $\mathrm{z}$ rewolweru ${ }^{32}$.

Aktywność prowokatorów nie ustała także w czasie samych świąt Bożego Narodzenia. Dnia 24 lub 25 grudnia 1943 roku w Ratułowie grupa dowodzona przez Arkularego i Hollera zastrzeliła Michała Szeligę. Razem z nim śmierć ponieśli Bolesław Byczkowski (vel Boczkowski), Jadwiga Styrczula oraz Bronisława Zawadzka ${ }^{33}$.

Działalność kierowanego przez Hollera i Arkularego prowokacyjnego oddziału trwała dalej, a po likwidacji Makówki dowodził nim przypuszczalnie „Ogrodnik”. Nie mając innych możliwości, dobrał on sobie do pomocy tolerowaną przez Niemców szajkę „Freibilliga”. Należeli do niej Józef Pacpaloch, Jan Kasperek oraz Józef Budz. W ten właśnie sposób grupa „Ogrodnika” stała się w powszechnym odczuciu miejscowych bandą „Freibilliga”. Z jednej strony jej zadaniem było tropienie współpracowników podziemia, szukanie kontaktów ze strukturami AK lub z pojedynczymi rozbitkami z grupy „Szaroty”, z drugiej natomiast odnajdywanie ukrywających się przed robotami w Rzeszy i „ciche” likwidacje niewygodnych Polaków. Z czasem działalność dywersyjną na rzecz Niemców niemal w całości zastąpiły przestępstwa pospolite. Wiosną 1944 roku miejscowa gmina złożyła oficjalną skargę do władz niemieckich na panoszącą się bandę, co zaowocowało likwidacją szajki przez żandarmerię. Wszystkich jej członków, wraz z „Ogrodnikiem” i „Freibilligiem”, rozstrzelano przed posterunkiem policji w Szaflarach w kwietniu 1944 roku $^{34}$.

\section{ODDZIAŁ „IM. LENINA”}

Na przełomie 1943 i 1944 roku w ważnym dla Niemców ze względów gospodarczych oraz komunikacyjnych powiecie miechowskim rozpoczęły się na większą skalę działania oddziałów partyzanckich - zarówno tych związanych z podziemiem niepodległościowym, jak i grup komunistycznych aktywizowanych oraz legitymizowanych przez miejscowe komórki PPR. Właśnie w związku z ożywioną działalnością tych ostatnich kierowany przez SS-Untersturmführera Phillipa Riedingera Komisariat Policji Kryminalnej w Miechowie, w porozumieniu z miejscowymi strukturami żandarmerii i dowódcą przerzuconego wiosną 1944 roku z Podhala do Pilicy 63. zmotoryzowanego plutonu żandarmerii, postanowił przygotować zakrojoną na większą skalę akcję prowokacyjną. Pomysłodawcami akcji byli najprawdopodobniej niemieccy żandarmi z plutonu Kreskego, którzy śledzili tego typu działania oraz

32 IPN Kr 07/926, Protokół przesłuchania świadka Stanisława Kuczka, 13 września 1945 r., k. 17; ibidem, Protokół przesłuchania świadka Ludwiny Kuczek, 8 września 1945 r., k. 19; ibidem, Protokół przesłuchania świadka Stanisława Kurkowskiego, 8 września 1945 r., k. 20.

33 W. Budarkiewicz, op. cit., s. 15; Rejestr miejsc i faktów zbrodni popetnionych przez okupanta hitlerowskiego na ziemiach polskich w latach 1939-1945. Województwo nowosądeckie, s. 99; IPN Kr 07/926, Protokół przesłuchania Marcina Litwina, [b.d.], k. 6.

34 W. Budarkiewicz, op. cit., s. 16; A. Marczyński, op. cit., s. 293. 
brali w nich czynny udział podczas zwalczania oddziału „Szaroty” i mogli zaświadczyć o ich skuteczności. Jej głównymi realizatorami mieli być natomiast polscy pracownicy policji kryminalnej, których zadaniem miało być stworzenie odpowiednio ucharakteryzowanego i „zalegendowanego” oddziału prowokacyjnego. O okolicznościach jego powstania zeznawał po latach jeden z jego członków - Zbigniew Biel:

W m-cu [marcu] 1944 r. zostałem przez Riedingera zawezwany wraz $\mathrm{z}$ innymi funkcj[onariuszami] policji kryminalnej [...] do [siedziby] starostwa [i] kancelarii kpt. Buczyńskiego [właśc. Wilhelm Buczinski], który był pow[iatowym] kom[endantem] żandarmerii niemieckiej na pow. miechowski. [...] Buczyński oraz Riedinger wskazali nam na mapie terenowej okolice pow. miechowskiego, w których [...] przebywają partyzanckie grupy komunistyczne [...] i powiedzieli do nas, że zadaniem naszym będzie udanie się do wspomnianych miejsc niby jako grupa partyzantów „Komunistycznych”35.

Głównym celem powołanej wówczas do życia grupy było, jak zeznawał po wojnie jeden z pracowników miechowskiego Kripo, Józef Śliwa: „rozpracowywanie podziemia, a szczególnie ugrupowań lewicowych, sporządzano listy osób podejrzanych [o przynależność do] organizacji lewicowych, skutkiem czego następowały pacyfikacje i wyłapywanie ludzi" ${ }^{36}$. Grupa prowokacyjna składała się z kilkunastu osób. Należeli do niej, ze strony tzw. polskiego Kripo: Zbigniew Biel, Stanisław Mazgaj, Mieczysław Ślusarek, Ludwik Stępień, Zbigniew Wiśniewski, Kazimierz Czepanis, Zbigniew Zakrzewski, Michał Mnichowski, Julian Rogosz i Henryk Puciński. Wszyscy oni byli odpowiednio wyposażeni, ubrani i uzbrojeni - Biel „,w płaszcz WP, czapkę baranią czarną z czerwoną gwiazdą, za pasem miał zapięty sowiecki granat oraz posiadał broń automatyczną P.P.-szę lub «Bertmana»", Mnichowski z kolei ubrany był w „wojskowe spodnie, w płaszczu ciemnozielonym, w kaszkiecie, posiadał automat «Sten»", a Stępień chodził w cywilnym płaszczu, „w czapce polowej WP, posiadał K.B.K." ${ }^{37}$. Pozostali byli ubrani po cywilnemu i uzbrojeni w broń krótką oraz karabiny. Starano się, żeby przynajmniej kilku miało na czapkach lub rękawach jednoznacznie kojarzony z komunistami emblemat w postaci czerwonej gwiazdy. Ażeby jeszcze bardziej upodobnić się do działających w tym czasie grup komunistycznych, członkowie oddziału zdecydowali się też nadać mu odpowiednią nazwę. W ten sposób narodził się oddział „im. Lenina”.

Poza kripowcami, wśród których część stanowili Polacy wysiedleni z Wielkopolski, dobrze posługujący się językiem niemieckim, w skład oddziału prowokacyjnego wchodzili także ubrani po cywilnemu niemieccy żandarmi z 63. zmotoryzowanego plutonu żandarmerii. Byli to: Wachtmeister der Gendarmerie der Reserve Johann

35 IPN Kr 07/2366, Akta kontrolno-śledcze w sprawie Bolesława Nieczui-Ostrowskiego i innych [dalej: IPN Kr 07/2366], t. 18, Protokół przesłuchania podejrzanego Zbigniewa Biela, Kraków, 20 listopada 1950 r., k. 331. Zob. IPN Kr 07/2366, t. 2, Protokół przesłuchania świadka Philippa Riedingera, Kraków, 8 stycznia 1951 r., k. 7-10; ibidem, t. 3, Protokół przesłuchania świadka Philippa Riedingera, Kraków, 20 listopada 1950 r., k. 81-83.

36 IPN Kr 075/1, Wywiad i kontrwywiad niemiecki [dalej: IPN Kr 075/1], t. 8, Protokół przesłuchania świadka Józefa Śliwy, Myślenice, 20 lipca 1952 r., k. 59.

37 IPN Kr 07/2366, t. 18, Protokół przesłuchania podejrzanego Józefa Śliwy, Kraków, 23 listopada 1950 r., k. 324. 
Ilnitzky, Wachtmeister der Gendarmerie der Reserve Paul Teuber, Oberwachtmeister der Gendarmerie der Reserve Johann Ledwon, Wachtmeister der Gendarmerie der Reserve Roman Grzeschik i Wachtmeister der Gendarmerie der Reserve Thomas Kubatzka. Dowódcą oddziału został Niemiec - doświadczony w walkach z „bandami" Zugwachtmeister der Gendarmerie Jakob Lübbers ${ }^{38}$. Wybór wymienionych żandarmów nie był przypadkowy. Ilnitzky pochodził z Ukrainy, stąd też przypuszczalnie władał bardzo dobrze językiem ukraińskim i rosyjskim, natomiast Ledwon, Grzeschik i Kubatzka pochodzili ze Śląska i posługiwali się językiem polskim. Ponadto grupa mogła też liczyć na wsparcie logistyczne ze strony funkcjonariuszy Sipo - Riedingera z Kripo oraz kierownika zamiejscowej placówki policji bezpieczeństwa i służby bezpieczeństwa w Miechowie SS-Hauptscharführera Franza Bösenköttera ${ }^{39}$.

Grupa po raz pierwszy wyszła w pole najprawdopodobniej 23 marca 1944 roku. Jak relacjonował Biel:

Operowaliśmy na terenie Gołczy, Gołyszyn, Czapel Wielkich, Czapel Małych [...]. Przez okres naszego pobytu w terenie w dzień przebywaliśmy u gospodarzy w ich zabudowaniach, w których równocześnie informowaliśmy się o innych grupach „Komunistycznych”. W nocy natomiast chodziliśmy po terenie, obserwując gdzie padnie jakiś strzał lub gdzie kto idzie, by się udać w tym kierunku celem nawiązania [u]pragnionego kontaktu ${ }^{40}$.

Próbowano między innymi namówić do udzielenia informacji leśniczego w Wyrwicach, u którego, w trakcie luźnej rozmowy przy wódce, nadmieniono o potrzebie skontaktowania się $\mathrm{z}$ działającą na tym terenie komunistyczną grupą dowodzoną przez nieznanego z nazwiska „Augusta II”41. Leśniczy zobowiązał się spróbować odnaleźć „Augusta II” - umówiono się, że grupa przyjdzie do niego za kilka dni.

38 Ibidem, t. 18, Protokół przesłuchania podejrzanego Zbigniewa Biela, Kraków, 20 listopada 1950 r., k. 331; IPN GK 107/41, Vorschlagliste Nr 3 für die Verleihung des Eisernen Kreuzes II. Klasse, Jakob Lübbers, Krakau, 18 stycznia 1944 r., k. 16-18; ibidem, Vorschlagliste Nr 36 für die Verleihung des Eisernen Kreuzes II. Klasse, Jakob Lübbers, Krakau, 24 maja 1944 r., k. 27-29; ibidem, Vorschlagliste $\mathrm{Nr} 37$ für die Verleihung des Kriegsverdienstkreuzes II. Klasse mit Schwerten, Johann Ilnitzky, Krakau, 24 maja 1944 r., k. 62-64; ibidem, Vorschlagliste Nr 45 für die Verleihung des Kriegsverdienstkreuzes II. Klasse mit Schwerten, Johann Ledwon, Roman Grzeschik, Thomas Kubatzka, Paul Teuber, Krakau, 19 czerwca 1944 r., k. 70-74.

39 IPN Kr 07/2366, t. 18, Protokół przesłuchania podejrzanego Józefa Śliwy, Kraków, 23 listopada 1950 r., k. 324.

40 Ibidem, Protokół przesłuchania podejrzanego Zbigniewa Biela, Kraków, 20 listopada 1950 r., k. 332 .

${ }_{41}$ IPN Kr 075/1, t. 8, Protokół przesłuchania świadka Zbigniewa Biela, Libiąż, 23 czerwca 1952 r., k. 66. W swoich zeznaniach Biel twierdził, że jednym z podstawowych zadań, jakie stawiano przed grupą, była likwidacja oddziału „Augusta II”. Składał się on z polskich komunistów oraz zbiegłych z niewoli Sowietów i działał jako grupa podporządkowana PPR. Funkcjonował od drugiej połowy 1943 do 13 maja 1944 r., kiedy został zlikwidowany w Imbramowicach przez oddział AL Jana Trzaski „Gutka”, który utrzymywał, że „August II” oraz jego kochanka Maria są na usługach Niemców. Zob. IPN BU 1558/416, Inspektorat AK Miechów [dalej: IPN BU 1558/416], Fragment maszynopisu, [b.m.d.], k. 190; ibidem, Notatka na temat PPR, [b.m.d.], k. 191; ibidem, Likwidacja Augusta II, [b.m.d.], k. 195; W. Ważniewski, Walki partyzanckie nad Nida 1939-1945, wyd. 2, Warszawa 1975, s. 184-185, 188. 
W międzyczasie kripowcy wrócili do Miechowa, a żandarmi do Pilicy ${ }^{42}$. Rzeczywiście po upływie paru dni grupa ponownie się zebrała i wyruszyła do leśniczego - on jednak w międzyczasie uciekł, o czym poinformowała ich jego żona. Biel zeznawał:

Po tym oświadczeniu udaliśmy się do [...] miejscowości Rzeplin, gdzie byliśmy całą noc i dzień. Wieczorem udaliśmy się do właściciela majątku Gołyszyn pow. Miechów gdzie dostaliśmy kolację i Libers [właśc. Lübbers] połączył się telefonicznie z Post[erunkiem] P[olicji] $\mathrm{P}$ [olskiej] w Tczycy gdzie zagroził, że mają się poddać i że ich wysadzi w powietrze ${ }^{43}$.

Oczywiście do niczego takiego nie doszło i jeszcze tej samej nocy grupa ponownie się rozwiązała, a funkcjonariusze, bez wyraźnych sukcesów, wrócili do swoich placówek.

Jedną z głośniejszych akcji, jakie wykonali funkcjonariusze tworzący oddział „im. Lenina”, była likwidacja kilkuosobowej grupy komunistów z oddziału „Augusta II", do której doszło w pierwszych dniach kwietnia 1944 roku. Oddział dowodzony przez Lübbersa i liczący 14 osób wyruszył wówczas nocą z Miechowa na zachód, w rejon, z którego wcześniej docierały do Niemców raporty o działalności komunistów. W okolicach miejscowości Krępa na wiejskiej zabawie natrafiono na ludzi należących do siatki PPR i uzyskano wówczas od nich informacje o miejscu stacjonowania komunistów. Przebranie „partyzantów” oraz ich zachowanie było na tyle sugestywne, że współpracownicy wskazali im leśniczówkę Barani Dół koło Czapli Wielkich, gdzie kwaterują członkowie grupy, podali także obowiązujące komunistów hasło. Jako przewodnika zabrano ze sobą miejscowego nocnego stróża, który wieczorem 5 kwietnia 1944 roku zaprowadził „przebierańców” do leśniczówki. Tam rozpoczęto wspólną biesiadę. Kiedy skończył się alkohol, dwóch kripowców oraz dwóch komunistów (obywatel sowiecki i Józef Królikowski z Wiktorki) wyszło z budynku, żeby zakupić wódkę. Była już godzina 2.00 nad ranem 6 kwietnia. Po kilku metrach kripowcy wyciągnęli pistolety i z bliska zastrzelili swoich dotychczasowych kompanów. „Likwidacja tych pierwszych czł[onków] G[wardii]L[udowej] była umówionym znakiem i hasłem, aby pozostali funkcj[onariusze] policji kryminalnej likwidowali pozostałych czł[onków] G.L. co też zostało dokonane"44. Na odgłos strzałów do akcji przystąpili też inni prowokatorzy, zabijając w leśniczówce, za pomocą broni palnej i granatów, kilku członków AL oraz znajdującego się tam przypadkiem przewodnika - nocnego stróża. $Z$ budynku udało się wyskoczyć trzem komunistom, z czego dwaj zostali zlikwidowani przez zabezpieczających teren niemieckich żandarmów - jeden koło płotu otaczającego leśniczówkę, drugi w wąwozie ok. 200 metrów od miejsca walki. Według relacji funkcjonariuszy Kripo podczas

42 W meldunku kontrwywiadowczym AK wspominano, że podczas tego patrolu prowokatorzy byli we dworze w Czaplach Małych, a 26 marca skonfiskowali u gospodarza Ciepki w Barbarce k. Skały płaszcze, kurtki, zegar i 10 kur, na co wydano pokwitowanie z podpisem: „Polska Partia Komunistyczna - Lenin". IPN BU 1558/419, Inspektorat AK Miechów, Raport KW za m-c marzec 1944 oraz ważne z kwietnia, 14 kwietnia 1944 r., k. 70.

43 IPN Kr 07/2366, t. 3, Protokół przesłuchania świadka Zbigniewa Biela, Kraków, 19 lutego 1951 r., k. 149. W. Ważniewski datuje wizytę prowokatorów w Gołyszynie na dzień 28 marca 1944 r. Zob. W. Ważniewski, op. cit., s. 186.

44 Ibidem, Protokół przesłuchania podejrzanego Józefa Śliwy, Kraków, 23 listopada 1950 r., k. 325. 
akcji zginęło dziewięć osób (ośmiu członków oddziału AL - Polaków i Sowietów - oraz nocny stróż), natomiast podczas ekshumacji przeprowadzonej w 1945 roku wydobyto szczątki siedmiu ludzi. Wśród zabitych rozpoznano poza Królikowskim także Józefa Andrusiewicza ${ }^{45}$. Dość dokładnie wydarzenie to przedstawiał sporządzony tydzień później raport AK:

Melduję, że grupa funkcjonariuszy kripo o której poprzednio donosiłem w dniu 6.3. [właśc. 6.04] o godzinie $1 \mathrm{w}$ nocy rozbiła oddział PPR na terenie Czapel Małych. Udawali oni oddział komunistyczny rozbity w kieleckim i prowadzili dłużzze pertraktacje z oddziałem Augusta celem połączenia się. Miejscem spotkania była leśniczówka Czaple Małe - po nadejściu PPR / bez Augusta/ po wspólnej libacji, pokazywaniu broni - otworzyli ogień na komunistów. Wynik walki - zabitych: J. Królikowski, J. Andrusiewicz /znani członkowie bandy Augusta II/ 1 rosjanin [tak w oryg.], 1 żyd [tak w oryg.], niezidentyfikowany komunista z Czapel. Uciekli: $1 \mathrm{c}[$ iężko] ranny rosjanin, 2 nierozpoznanych. [...] Ze strony kripo strat nie ma ponieważ działali zaskoczeniem. Na pismach jakie przy pierwszym porozumieniu pisali - dca ich podpisywał się: dca. grupy „Lenin” - Zenon ${ }^{46}$.

Fakt likwidacji polsko-sowieckiej „bandy” potwierdzają także dokumenty żandarmerii niemieckiej, w tym Rozkaz Dzienny Komendanta Żandarmerii w Dystrykcie Krakowskim z 9 maja 1944 roku, w którym udzielił imiennych pochwał za realizację tej akcji Lübbersowi, Ledwoniowi, Ilnitzkiemu oraz Grzeschikowi ${ }^{47}$. Na akcję zareagowali także miejscowi komuniści, którzy w swoim organie prasowym „Głos Miechowa” opublikowali 1 maja 1944 roku następujące ostrzeżenie o prowokatorach:

Na terenie powiatu miechowskiego od dwóch tygodni zbiry hitlerowskie wypuściły oddział KP-o [Kripo] w sile 11 ludzi, którzy udają partyzantów. Noszą cywilne ubrania, czerwone kokardki, zatrącają niemczyzną, nawołują do wstępowania do PPR i oddziałów partyzanckich. Zajmują kwatery po wioskach, rabują mienie, maltretują ludność. Obywatele Chłopi! Ostrzegamy Was, że to jest jeden $\mathrm{z}$ dalszych tricków hitlerowskich $\mathrm{w}$ celu wytępienia narodu polskiego. Ostrzegamy Was, byście się nie dawali wciągać w żadne dyskusje, następnie nie udzielali żadnej pomocy oraz powiadomili sąsiednie wioski o pojawieniu się takiego oddziału. Po wymaszerowaniu takiego oddziału strzeżcie się przed aresztowaniami ${ }^{48}$.

O dalszej aktywności groźnej dla podziemia grupy donosiły wiosną 1944 roku raporty miejscowych struktur $\mathrm{AK}$, w których trafnie nazywano ją ,partyzantką pseudokomunistyczną" utworzoną przez Gestapo. Wspominano m.in., że na skutek jej działalności 23 kwietnia doszło do obławy w Krępie, podczas której zatrzymano łącznie 48 osób i zastrzelono Józefa Wydmańskiego oraz ukrywającego się u niego Żyda ${ }^{49}$. „Spośród areszt[owanych] była przeważająca liczba sprowokowanych przez

45 Ibidem, Protokół przesłuchania podejrzanego Zbigniewa Biela, Kraków, 20 listopada 1950 r., k. 333; Rejestr miejsc i faktów zbrodni popetnionych przez okupanta hitlerowskiego na ziemiach polskich w latach 1939-1945. Województwo krakowskie miejskie, Warszawa 1984, s. 22-23; J. Guzik, Racławickie wezwania. Monografia okupacyjna ziemi miechowskiej 1939-1945, Wawrzeńczyce 1987, s. 212.

46 IPN BU 1558/416, 2d/5555 do 5555, 11 kwietnia 1944 r., k. 109.

47 AP Przemyśl, Zespół nr 24, sygn. 33, Der Kommandeur der Gendarmerie im Distrikt Krakau, Tagesbefehl, Krakau, 9 maja 1944 r., k. 198.

48 W. Ważniewski, op. cit., s. 187-188.

49 Rejestr miejsc i faktów zbrodni popetnionych przez okupanta hitlerowskiego na ziemiach polskich w latach 1939-1945. Województwo krakowskie miejskie, s. 55. 
Kripo ochotników do band leśnych" 50 . W jednym z raportów podawano nawet skład, jak to określano, „,bandy udającej dywersję”. Informacje podziemia były precyzyjne - mowa w nich była o pięciu żandarmach z „Motzugu” Żarnowiec oraz kilku kripowcach (wymienieni zostali z nazwiska Biel, Mnichowski, Stępień i Puciński) ${ }^{51}$. Warto zacytować fragment meldunku dotyczący jej działalności: „W nocy z 15 na 16.V.1944 grupa około 20 do 30 osób pozorująca PPR złożona z niemców [tak w oryg.] i kripo zjawiła się w maj[ątku] Rzeplin, gm[ina] Minoga, wypytując o «burżujską» organizację AK, która umaczała ręce w ich krwi, mordując Augusta II i groziła odwetem"52. Zdając sobie sprawę, że są to przebrani funkcjonariusze niemieckiej policji, zdecydowano się, najprawdopodobniej za zgodą AK, powiadomić o ich aktywności niemiecką żandarmerię w Skale. Nie spowodowało to jednak żadnej reakcji ze strony okupantów, którzy doskonale wiedzieli o zadaniach, jakie realizowała na tym terenie grupa Lübbersa. „Banda ubrana była we furażerki z wyszytymi na nich czerwonymi gwiazdkami, kilku miało polskie płaszcze wojskowe, czerwone proporczyki i czerwone szaliki. /przesada obliczona na naiwność ludzką/. Uzbrojeni po zęby: po 2 pistolety, kb, 6 ładownic, granaty, 3 RKM, pasy główne naramienne"53. Z Rzeplina prowokatorzy przejechali do lasu majątku Wysocice i dalej do Wiktorki w gminie Gołcza. Napotkanym po drodze robotnikom leśnym i fornalom opowiadali, że są sowieckimi „desantami” oraz że zlikwidują ludzi z organizacji, która doprowadziła do rozbicia grupy „Augusta II”.

Dopytywali się, czy nie ma takich, którzyby donosili niemcom [tak w oryg.] co dzieje się w okolicy. Kilku kripowcom udało się sprowokować mieszkańca miej[scowości] Żarnowicach [najprawdopodobniej chodzi o Żarnowicę] nazw[iskiem] Grodowski, który dając im posiłek wyraził się, że dałby im więcej i lepiej gdyby tych przeklętych niemców już raz stąd usunęli. Prowokatorzy odeszli pozostawiając w stodole wym[ienionego] RKM. Wkrótce nadeszli żandarmi, twierdząc, że była u niego banda, pozostawiając w stodole rkm. Ponieważ G. zaparł się przeprowadzono rewizję, znalazłszy broń aresztowano go wraz z zięciem i córkami ${ }^{54}$.

Ponadto, za sprawą działań grupy prowokacyjnej, aresztowani zostali w tym czasie niejaki Bocianiec, służący leśniczego Romana Janczarskiego z Wysocic, oraz nauczyciel syna leśniczego - Zduniak ${ }^{55}$. Wieczorem 17 maja pseudopartyzanci ponownie weszli do lasów obok Wiktorki i po zmroku urządzili strzelaninę, pozorując starcie z Niemcami (rozpowiadali następnie miejscowym gospodarzom, że w jego trakcie dwóch z nich poległo). Po tym wydarzeniu, według raportu AK, rozwiązano grupę i połączono się z oczekującą na ich powrót żandarmerią niemiecką. Jeszcze

50 IPN BU 1558/544, Inspektorat AK Miechów [dalej: IPN BU 1558/544], Fragment maszynopisu, [b.m.d.], k. 135.

${ }_{51}$ Ibidem, Fragment raportu, [b.m.d.], k. 243-244.

52 IPN Kr 07/2366, t. 1, B/KW do I, Raport za miesiąc maj 1944 r. (odpis), 13 czerwca 1944 r., k. 15. Por. IPN BU 1558/416, Fragment maszynopisu, [b.m.d.], k. 189.

53 Ibidem.

54 IPN Kr 07/2366, t. 1, B/KW do I, Raport za miesiąc maj 1944 r. (odpis), 13 czerwca 1944 r., k. 15.

55 Ibidem. 
w nocy z 17 na 18 maja przeprowadziła ona na podstawie wywiadu pseudopartyzantów rewizje i aresztowania w Ściborzycach ${ }^{56}$.

Miejscowe struktury AK donosiły też o jeszcze jednej wyprawie, jakiej w maju 1944 roku dokonali podający się za „leśnych” funkcjonariusze Kripo i żandarmerii. Tym razem, najprawdopodobniej między 21 a 22 maja, prowokatorzy grasowali na terenie Sułoszowej, gdzie przeszukiwali „chlewy i mieszkania, wypytywali o patriotów Polaków i zachęcali do przystępowania do nich" ${ }^{57}$. Akces do oddziału zgłosił jedynie miejscowy listonosz, który przypłacił to aresztowaniem, gdy na terenie Sułoszowej między 22 a 24 maja, tuż po wizycie prowokatorów, pojawili się niemieccy żandarmi. Zatrzymali oni w Sułoszowej siedem, a w Kosmolowie osiem osób - przede wszystkim ludzi posiadających niekolczykowane bydło lub nieprzestrzegających godziny policyjnej. Pośród aresztowanych był jednak także żołnierz AK, przy którym znaleziono nielegalną gazetkę ${ }^{58}$.

Działania „w przebraniu” kontynuowano także w kolejnych miesiącach. Latem 1944 roku w okolicach Pilicy prowokatorzy zlikwidowali dwóch szmuglerów, zabierając im mienie, oraz dwóch partyzantów AK - trzeciego rannego przywieziono do Miechowa i dopiero tam zastrzelono ${ }^{59}$. Jednym z uczestników tej akcji miał być Michał Mnichowski, który jednakże kilka miesięcy później, podczas przesłuchania przed sądem polowym AK, zeznawał, że nigdy nie działał na szkodę niepodległościowego podziemia. Mówił:

Na dowód, że zawsze byłem Polakiem podaję to, że kiedy służyłem w Kripo wysłali mnie oraz czterech innych kripowców oraz pięciu niemców [tak w oryg.] w okolice Skała/Ojców, ażeby udawać komunistów rosyjskich. [...] Kiedy razem ze Ślusarkiem jako pierwsi weszliśmy do leśniczego w Skale leśniczy powiedział mi, że jest tam ranny, na to kazałem jego usunąć, ostrzegłem że zaraz za mną przyjdą niemcy [tak w oryg.]. Uratowałem w ten sposób kilka osób ${ }^{60}$.

Mnichowski nie był chyba w tym zeznaniu całkowicie szczery, zwłaszcza że wszyscy wymieniali go jako jednego z bardziej aktywnych członków grupy prowokacyjnej, który miał też osobiście odpowiadać za aresztowanie, a następnie likwidację latem 1944 roku czteroosobowej rodziny żydowskiej Glazmanów na terenie Pilicy ${ }^{61}$.

Ostatnim przejawem działalności grupy miało być rzekomo rozpracowanie struktur $\mathrm{BCh}$ w okolicach Pilicy i Wolbromia, na skutek czego aresztowano ok. 10 członków BCh, z których większość wysłano do KL Auschwitz. Dalszą

56 Aresztowani mieli być tej nocy także: szewc Bronisław (lub Bolesław) Adamczyk z Luborzycy, nauczyciel Piotr Skrzypczak, ojciec Jana Bubki „Staszka” ze Ściborowic oraz „dwóch Derdasiów”. Por. Rejestr miejsc i faktów zbrodni popetnionych przez okupanta hitlerowskiego na ziemiach polskich w latach 1939-1945. Województwo krakowskie miejskie, s. 33-34.

57 IPN BU 1558/416, Aresztowania i represje, [b.m.d.], k. 154.

58 Ibidem.

59 IPN Kr 07/2366, t. 18, Protokół przesłuchania podejrzanego Józefa Śliwy, Kraków, 23 listopada 1950 r., k. 325-326; IPN BU 1558/414, Inspektorat AK Miechów [dalej: IPN BU 1558/414], 1/I do 1/VII dla Maja, [b.m.d.], k. 48.

${ }^{60}$ Muzeum Historyczne Miasta Krakowa, Zbiory Andrzeja Szczygła, Zespół IV batalionu 1. psp AK, Protokół spisany ze strzelca Żbika, k. 289.

${ }_{61}$ IPN $\mathrm{Kr}$ 07/2366, t. 18, Protokół przesłuchania podejrzanego Józefa Śliwy, Kraków, 23 listopada 1950 r., k. 326. 
działalność prowokatorów przerwała ofensywa sowiecka i zmiana polityki Niemców wobec podziemia niepodległościowego w powiecie miechowskim. Ponadto szeregi oddziału topniały po wyrokach śmierci, jakie na kripowców wydały miejscowe struktury Polskiego Państwa Podziemnego. Ludwik Stępień został 5 czerwca 1944 roku zastrzelony koło Proszowic (przypuszczalnie przez patrol AK) ${ }^{62}$. Dwaj inni członkowie oddziału „im. Lenina” zginęli w nie do końca wyjaśnionych okolicznościach. Julian Rogosz został 10 kwietnia 1944 roku zastrzelony przez volksdeutscha Adolfa Folmera po sprzeczce, jaka wynikła między nimi w jednej z miechowskich restauracji, a Henryk Puciński pod koniec 1944 roku popełnił samobójstwo ${ }^{63}$.

\section{KRES DZIAŁAŃ PROWOKACYJNYCH}

Analiza dostępnych źródeł pozwala dojść do wniosku, że w żadnych innych powiatach dystryktu krakowskiego działalność grup prowokacyjnych nie była tak intensywna, jak w powiecie nowotarskim, a następnie miechowskim. Jednak także i tam w połowie 1944 roku nastąpił jej kres. Ofensywa Armii Czerwonej w lipcu 1944 roku i związana z tym rozbudowa komunistycznej partyzantki, a także mobilizacja oddziałów Armii Krajowej do realizacji akcji „Burza”, sprawiły, że obszar powiatu miechowskiego stał się areną zupełnie innych zmagań, w których nie było już miejsca na dotychczasową aktywność prowokatorów. Byli oni zresztą już dokładnie rozpracowani i znano ich metody działania - m.in. za sprawą Waleriana Kosałki „Dziarskiego”, wywiadowcy AK pracującego w miechowskim Kripo. Niemcom nie zależało też w tym czasie na tym, żeby nękać akowców tego typu działaniami. Starali się bowiem nawiązać z podziemiem współpracę i zwrócić struktury niepodległościowej konspiracji przeciw komunistom. I choć celu tego nie udało im się zrealizować, to licząc na przychylność podziemia, w znacznym stopniu ograniczyli represje.

Niewykluczone, że w tym czasie zdecydowano też ponownie spróbować działalności prowokacyjnej w innym zakątku Małopolski - na pograniczu Podhala i Sądecczyzny. Do Nowego Sącza skierowano sprawdzony w tego typu akcjach zmotoryzowany pluton żandarmerii Kreskego, a w Szczawnicy urządzono szkolenie dla pracowników „granatowej” policji, którzy, jak relacjonowano, tworzyć mieli w przyszłości pod okiem żandarmów wyspecjalizowane oddziały do walk z partyzantami. Pomysł ten nie doczekał się jednak realizacji, gdyż z chwilą uruchomienia akcji „Burza” duża część policjantów ze Szczawnicy zdezerterowała i przyłączyła się do miejscowych oddziałów $\mathrm{AK}^{64}$. Znalazł się w nich także znany z działań w Miechowskiem polski funkcjonariusz Kripo Michał Mnichowski. Został nawet partyzantem

62 IPN BU 1558/544, Inspektorat AK Miechów, Notatka odręczna, [b.m.d.], k. 114; ibidem, 5555, O. likw. konf., [b.m.d.], k. 299.

${ }_{63}$ Ibidem, Fragment meldunku, [b.m.d.], k. 213.

64 D. Golik, Partyzanci „Lamparta”. Historia IV batalionu 1. pułku strzelców podhalańskich AK, Kraków 2014, s. 147-155. 
IV Batalionu 1. Pułku Strzelców Podhalańskich AK i przyjął pseudonim „Żbik”. Twierdził, że zdezerterował z Kripo, zabierając ze sobą broń krótką i zdecydował się wstąpić do podhalańskiej partyzantki. Niewykluczone, że mogła to być prawda i tym razem Mnichowski nie wykonywał żadnej akcji prowokacyjnej na rzecz Niemców. Niemniej jednak przyjmując go w szeregi AK, zdecydowano się sprawdzić, jaką cieszył się opinią w powiecie miechowskim. Chociaż zapytanie wysłano w październiku (po ponad dwóch miesiącach służby Mnichowskiego w AK), to odpowiedź w jego sprawie nadeszła dopiero 2 listopada 1944 roku. Szef Inspektoratu AK Miechów major Bolesław Nieczuja-Ostrowski „Bolko” pisał w niej:

Mnichowski był na usługach gepo z którego polecenia wypełniał różne powierzane mu zadania pobierając za nie odpowiednie premie. Znany dobrze jako konfident. [...] Mnichowski strzelał Polaków z własnej inicjatywy bądź też z rozkazu gepo. Wiosną 44 r. w okolicy Pilicy postrzelił żołnierza AK stałego mieszkańca Pilicy a następnie dostawił go do gepo wraz ze stenem jaki posiadał ów żołnierz. Zatrzymanego po przesłuchaniu zastrzelono. Wymieniony poszukiwany jest przez nas jako niebezpieczny konfident ${ }^{65}$.

Najprawdopodobniej w związku z tą opinią oraz innymi zarzutami, jakie ciążyły na „Żbiku” i kilku innych partyzantach, dowodzący batalionem kapitan Julian Zapała „Lampart” zdecydował się na jego likwidację, która nastąpiła w nocy z 28 na 29 listopada $1944 \mathrm{roku}^{66}$.

\section{$* * *$}

Działalność niemieckich oddziałów prowokacyjnych jest jedną z najmniej znanych i najsłabiej zbadanych metod zwalczania podziemia na terenie Generalnego Gubernatorstwa, która wciąż czeka na całościowe opracowanie. Wszystko wskazuje bowiem na to, że przedsięwzięcia, jakie policja niemiecka realizowała w dystrykcie krakowskim w 1943 i 1944 roku, nie były odosobnione i tego typu działania miały miejsce na terenie całej okupowanej Polski ${ }^{67}$. Bezsprzecznie istnieć musiały konkretne wytyczne i instrukcje odnośnie do tego, jak tworzyć i wykorzystywać takie grupy oraz jakie piony policji niemieckiej mają za to odpowiadać. Mimo że nie udało się ich jak dotąd odnaleźć, to opisane wyżej przypadki pozwalają poczynić pewne spostrzeżenia na ten temat.

Przede wszystkim tworzone przez Niemców oddziały prowokacyjne budowane były we współpracy dwóch najważniejszych pionów policji niemieckiej - policji bezpieczeństwa i służby bezpieczeństwa oraz policji porządkowej. Policję bezpieczeństwa i służbę bezpieczeństwa reprezentowali funkcjonariusze Gestapo, którzy dostarczali informacji o działających w terenie grupach zbrojnych i organizacjach konspiracyjnych, a także ich sposobie funkcjonowania i wyglądzie partyzantów. Mogli służyć swoją agenturą i informatorami, niekiedy też osobiście angażowali się

${ }_{65}$ IPN BU 1558/414, 1/I do 1/VII dla Maja, 25 października 1944 r., k. 48.

66 D. Golik, Partyzanci..., s. 399-400.

${ }_{67}$ Przejawy takiej działalności zostały przebadane m.in. dla dystryktu radomskiego. Zob. T. Domański, Prowokacje niemieckich oddziatów policyjnych $i$ wojskowych na terenach wiejskich dystryktu radomskiego. Zarys problematyki, „Polska pod Okupacją 1939-1945” 2016, t. 2, s. 149-166. 
w działania prowokatorów, ale warunkiem ku temu była z reguły znajomość języka polskiego lub rosyjskiego. O wiele istotniejszą $\mathrm{w}$ akcjach prowokacyjnych była jednak rola Kripo. Niemieccy funkcjonariusze tej formacji na co dzień pracowali z Polakami, typowali też do działań w cywilu swoich podwładnych, którzy się w nich wielokrotnie sprawdzali. Polscy kripowcy okryli się w związku z tym złą sławą i pozostawali do końca wojny „na celowniku” podziemia jako groźni i wyrachowani przeciwnicy. Z kolei w szeregach policji porządkowej bardzo istotną rolę w tworzeniu „kontrband” odgrywali niemieccy żandarmi, zarówno ci z lokalnych posterunków żandarmerii, jak i funkcjonariusze wysyłanych z miejsca na miejsce plutonów zmotoryzowanych. Część z nich była przed wojną obywatelami Polski lub ZSRS, stąd też mogła bez problemu wcielać się w rolę partyzantów oraz pełnić funkcję tłumaczy. Fakt obecności w oddziałach żandarmów nadawał im również bardziej sformalizowany charakter, gwarantował też, że „przebierańcy” nie przejdą na stronę przeciwników. Ponadto pewną pomoc, zwłaszcza w początkowym okresie działalności, otrzymywano także od Polaków służących w ,granatowej” policji, którzy dobrowolnie lub pod przymusem współtworzyli oddziały prowokacyjne. Bez polsko- lub rosyjskojęzycznych funkcjonariuszy policji prowokacje nie byłyby możliwe.

Trudno bez dalszych badań ocenić skuteczność prowokatorów - mogła być jednak duża, zwłaszcza w 1943 i w pierwszej połowie 1944 roku, gdy za ich pomocą likwidowano, często dopiero tworzące się i nie dość dobrze dbające o zasady konspiracji, lokalne grupy zbrojne. Co więcej, oddziały prowokacyjne okazywały się szczególnie niebezpieczne dla współpracowników partyzantów i ludności cywilnej, która nie zdając sobie sprawy, z kim ma do czynienia, udzielała ich członkom wsparcia. I o ile struktury AK, a następnie także siatki komunistyczne, w miarę szybko orientowały się w metodach działania takich grup i unikały z nimi styczności, o tyle cywile pozostawali w takich sytuacjach zupełnie bezbronni...

\section{BIBLIOGRAFIA}

\section{Dokumenty archiwalne}

AOKBZpNP IPN w Krakowie, Ds 6/70, Zbrodnie funkcjonariuszy Gestapo w Zakopanem AOKBZpNP IPN w Krakowie, S 9/76, Rozstrzelanie 22 Polaków na terenie gminy Chochołów (w Chochołowie, Dzianiszu i Witowie) w okresie od stycznia 1940 do $1944 \mathrm{r}$.

AP Przemyśl, Zespół nr 24, sygn. 33, Polizeibeamte. Einsatz der deutschen Gendarmerie 1940-1944.

Bundesarchiv Berlin-Lichterfelde, R 9361-III/107131, Herbert Kreske.

Bundesarchiv Berlin-Lichterfelde, VBS 286/6400023894, Herbert Kreske.

IPN BU 1558/414, Inspektorat AK Miechów.

IPN BU 1558/416, Inspektorat AK Miechów.

IPN BU 1558/419, Inspektorat AK Miechów.

IPN BU 1558/544, Inspektorat AK Miechów. 
IPN GK 107/33, Wnioski awansowe policji niemieckiej.

IPN GK 107/39, Wnioski awansowe policji niemieckiej.

IPN GK 107/41, Wnioski awansowe policji niemieckiej.

IPN Ka 047/417, Akta w sprawie Antoniego Arkulary.

IPN Kr 07/926, Akta kontrolno-śledcze w sprawie Antoniego Arkularego.

IPN Kr 07/1716, Akta kontrolno-śledcze w sprawie Andrzeja Lewandowskiego.

IPN Kr 07/2366, Akta kontrolno-śledcze w sprawie Bolesława Nieczui-Ostrowskiego i innych.

IPN Kr 010/9468, Akta operacyjne w sprawie Henryka Schwenka.

IPN Kr 075/1, Wywiad i kontrwywiad niemiecki.

Muzeum Historyczne Miasta Krakowa, Zbiory Andrzeja Szczygła, Zespół IV batalionu 1. psp AK.

\section{Wspomnienia niepublikowane}

Budarkiewicz W., Wspomnienia partyzanta podhalańskiego, mps, Nowy Targ 1986 (kopia w zbiorach autora).

Sral J., Pamiętnik Krasnego, rkps, [b.m.d.] (kopia w zbiorach autora).

\section{Artykuły w czasopismach naukowych}

Domański T., Prowokacje niemieckich oddziałów policyjnych $i$ wojskowych na terenach wiejskich dystryktu radomskiego. Zarys problematyki, „Polska pod Okupacją 1939-1945” 2016, t. 2.

Golik D., Oddział partyzancki Wojciecha Bolesława Duszy „Szaroty”, „Z Dziejów Walk o Niepodległość" 2015, t. 3.

Marczyński A., Wojciech Bolesław Dusza, ps. „, Szarota”, w walce z okupantem hitlerowskim na Podhalu w latach 1941-1943, „Studia Historyczne” 1983, R. XXVI.

\section{Książki, monografie}

Czech T.L. „Wicek”, Tym groźniejszy, że zdecydowany zginąć, Stary Sącz 1989 (wydanie na prawach rękopisu).

Golik D., Partyzanci „Lamparta”. Historia IV batalionu 1. pułku strzelców podhalańskich $A K$, Kraków 2014.

Guzik J., Racławickie wezwania. Monografia okupacyjna ziemi miechowskiej 1939-1945, Wawrzeńczyce 1987.

Hempel A., Pogrobowcy klęski. Rzecz o policji „granatowej” w Generalnym Gubernatorstwie 1939-1945, Warszawa 1990.

Korkuć M., Józef Kuraś „,Ogień”. Podhalańska wojna 1939-1945, Kraków 2011.

Kuczaj J., Ocalić od zapomnienia, z. 2, Calgary 1998.

Maciaszek M., Od „,Orta” do „Zawiszy”. Gorce 1943, Nowy Targ 2010. 
Rejestr miejsc i faktów zbrodni popetnionych przez okupanta hitlerowskiego na ziemiach polskich w latach 1939-1945. Województwo krakowskie miejskie, Warszawa 1984.

Rejestr miejsc $i$ faktów zbrodni popetnionych przez okupanta hitlerowskiego na ziemiach polskich $w$ latach 1939-1945. Województwo nowosądeckie, Warszawa 1984. Sikora Z., Krwawy ślad. Nieznani bohaterowie Podhala, Zakopane 2014.

Stachiewicz P., Akcja Koppe, Warszawa 1975.

Szepelak W., Ja przetrwatem..., Nowy Targ 2003.

Ważniewski W., Walki partyzanckie nad Nida 1939-1945, wyd. 2, Warszawa 1975.

\section{Materiały internetowe}

www.volksbund.de [dostęp: 24.08.2016]. 